DOI: 10.12731/2070-7568-2020-4-396-414

УДК 332.1

\title{
СОЦИАЛЬНО-ПСИХОЛОГИЧЕСКИЕ ОСОБЕННОСТИ РОССИЙСКО-БЕЛОРУССКИХ ПРИГРАНИЧНЫХ ТЕРРИТОРИЙ
}

Кузавко А.С., Шевченко О.А.

Цель - выявление специифики социально-психологических мотивов жителей, определяющих возможности и основные угрозы в становлении бизнес единицы в приграничном регионе.

Метод или методология проведения работы: в статье использовались преимущественно общенаучныле методы анализа и синтеза, обобщения и моделирования исследуемой предметной области.

Результаты: фактор географической близости двух государств проявляется как на уровне этнической принадлежности, так и готовности к сотрудничеству и взаимодействию на лично-бытовом и межгосударственном уровне. В статье представлен анализ социально-психологические особенностей жителей Днепро-Двинского региона (Смоленской, Витебской, Могилевской областей) методом анкетирования с закрытыми и открытыми уточняющими вопросами. Одной из главных задач исследования стало выявление отношения российско-белорусской молодежи к процессам интеграции России и Республики Беларусь. Наиболее оптимальным форматом взаимодействия двух приграничных государств, по мнению респондентов, является «независимое существование двух стран с тепльми и дружескими взаимоотношениями».

Область применения результатов: результаты исследования будут полезны научным работникам и специалистам, занимающился вопросами развития приграничных регионов, а также демографическими изменениями с учетом региональной специфики.

Ключевые слова: приграничные территории; социально-демографические особенности; межгосударственная интегращия; Днепро-Двинский регион. 


\section{SOCIO-PSYCHOLOGICAL FEATURES OF RUSSIAN-BELARUSIAN BORDER AREAS}

\section{Kuzavko A.S., Shevchenko O.A.}

Purpose. Identification of the specifics of the socio-psychological motives of residents that determine the opportunities and main threats in the formation of a business unit in the border region.

Methodology the article used mainly general scientific logical methods of analysis and synthesis, generalization and modeling of the subject area.

Results: the factor of geographical proximity of the two States is manifested both at the level of ethnicity and readiness for cooperation and interaction at the personal, domestic and interstate levels. The article presents an analysis of the socio-psychological characteristics of residents of the Dnieper-Dvina region (Smolensk, Vitebsk, Mogilev regions) using a questionnaire with closed and open clarifying questions. One of the main tasks of the study was to identify the attitude of Russian-Belarusian youth to the integration processes of Russia and the Republic of Belarus. According to respondents, the most optimal format for interaction between the two border States is «the independent existence of two countries with warm and friendly relations».

Practical implications the results of the study will be useful for researchers and specialists involved in the development of border regions, as well as demographic change, taking into account regional specifics.

Keywords: border region; socio-demographic characteristics; interstate integration; Dnieper-Dvina region.

\section{Введение}

Национальной идентичности отводится особое место в вопросах межгосударственного взаимодействия. Так, А.В. Бредихиным в работе [3] представлен достаточно подробный анализ исторических предпосылок к становлению славянских идентичностей. Коноваловым С.А. описаны этапы оценки идентичности региона 
как нематериального фактора развития региональной экономики и обосновано, что отсутствие какого-либо из условий положительной региональной идентичности приведет к созданию негативных проявлений, снижающих уровень конкурентоспособности региона [8]. Г.К. Ахвердян [2] и О.А. Кацук В.Н. Рябых [6] отмечают особую роль национального самосознания, самоидентификации и цивилизационного фактора именно в настоящее время, определяя данные направления ключевыми для устойчивого развития конкурентоспособности территорий в условиях глобализации и интеграционных процессов. Е.В. Еремина также подчеркивает, что идентичность территории оказывает существенное влияние на содержание и характер межрегиональных взаимодействий [4]. M. Alexandrov pacсматривает национальную идентичность как инструмента стратегического взаимодействия между государствами [12]. В свою очередь Н.И.Чернобровкина [11] предлагает выделять специфику данного понятия на макро и микроуровнях, определяя ключевые факторы развития территорий на каждом их них.

Традиционно это понятие определяется как ощущаемая человеком принадлежность к той или иной нации или этносу с его культурно-историческими и психологическими особенностями, проживанием на одной территории. В то же время сегодня маркерами реальности являются стирание границ [15], увеличение скорости передачи информации [13], непрестанный рост миграции, академическо-образовательной, трудовой, туристической мобильности, а также владение несколькими иностранными языками [16]. На межгосударственном уровне это выражается в стремлении различных государств создавать те или иные интеграционные объединения (Европейский союз, ЕАЭС), торгово-экономические и военные блоки (НАТО, ОДКБ и т.д.).

Это, с одной стороны, формирует условия для развития идеологии космополитизма, которая ставит интересы мирового гражданства выше интересов отдельной нации или государства, рассматривает человека как свободного индивида в рамках Земли. С другой стороны, новое звучание и популярность приобретают идеи 
сохранения национальных традиций, культурного кода, национальной специфичности. В этой связи наблюдается рост популярности правых партий, борьбы с миграцией, ограничительных мер для нетитульных наций, к примеру, в Европейском союзе. В целом эти предложения согласуются с гипотезами и прогнозами, связанными с теория эндогенного роста и новые модели экономической географии, которые подчеркивают роль взаимодействий между агентами, которые, например, приводят к тому, что экономическая деятельность агломерат в одних районах и не в других [14].

Отношение к вопросу национальной идентичности на территории стран постсоветского пространства в XXI веке имеет свою специфику. Создание независимых государств постепенно подтолкнуло к поиску новых национальных героев, созданию новых мифологем, переписыванию истории, подчас разрушающему старые культурноисторические ценности. Анализ российского и европейского опыта, проведенный Кузнецовым А.В. и Кузнецовой О.В., позволяет говорить о такой особенности российской политики в области социально-экономического развития приграничных территорий как излишняя концентрация на соображениях территориальной целостности и национальной безопасности, что несет в себе риски недоиспользования потенциала развития внешнеэкономических связей [10].

Согласно Концепции внешней политики РФ [1] развитие приграничного сотрудничества и межрегионального взаимодействия является важной составляющей двусторонних отношений с государствами и регионами в торговой, экономической, гуманитарной и других сферах. Особняком стоят вопросы изучения установок молодых людей, сходных этнических групп, в частности, восточнославянских народов. Они, как показывают исследования В. Кириенко, характеризуются значительным количеством сходных ментальнопсихологических характеристик, реакций на мир [5,7]. С момента документального закрепления намерений двух независимых государств - Российской Федерации и Республики Беларусь - строить единое социально-экономическое пространство - Союзное государство - прошло более 20 лет. Обусловленное общностью и неразрыв- 
ностью исторических судеб двух братских народов, основанное на принципах синергии, транспарентности и доверия сотрудничество направлено на укрепление интеграционных процессов.

\section{Методика}

В рамках настоящего исследования был проведен опрос 350 респондентов методом анкетирования с закрытыми и открытыми уточняющими вопросами жителей Днепро-Двинского региона (Смоленской (РФ), Витебской, Могилевской (РБ) областей) [9]. Анализ проводился преимущественно среди молодых людей от 16 до 25 лет во второй половине 2020 г. Опрос проводился для выявления социально-психологического особенностей населения приграничных территорий, как один из основных субъектов межгосударственного взаимодействия. Выявление данных специфических черт даст возможность оценки принимаемых социально-экономических мер на региональном уровне и сформирует основу для прогнозирования динамики изменения ситуации. Кроме того, важно определить отношение молодежного сообщества Днепро-Двинского региона к вопросу национальной идентичности, оценке социально-экономического положения территорий, его внешнеполитические предпочтения, миграционные настроения, лояльность к вхождению в те или иные межгосударственные объединения.

Эмпирические данные, касающиеся представленности в менталитете молодого жителя приграничья понятия национальной идентичности и его внешнеполитической лояльности, были разбиты на следующие блоки:

1) сходство и различия русских и белорусов, восприятие друг друга;

2) внешнеполитические предпочтения молодых жителей приграничья, готовность к интеграции и ее формы.

\section{Результаты исследования}

По первому блоку вопросов выяснено, что все опрошенные выделяют в качестве критериев сходства:

- общее славянское происхождение: на это указывают 76\% смолян, 76\% могилевчан и 54\% витеблян; 
- историю, общие испытания и победы: на это указывают 55\% витеблян, $52 \%$ смолян, $47 \%$ могилевчан;

- культуру, язык: на это указывают 46\% могилевчан, 41\% витеблян; $33 \%$ смолян.

Имеет место специфика ответов на данный вопрос в каждом из регионов (рис. 1).

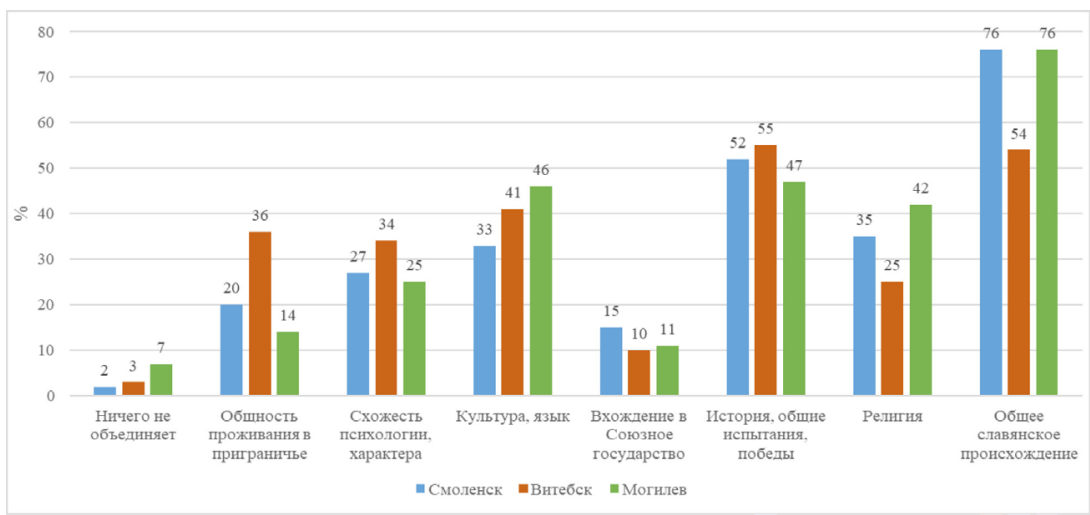

Рис. 1. Что объединяет народы ДДР

Так, молодежь Смоленской области в качестве третьего фактора сходства выделяет религию: $35 \%$ опрошенных. 36\% респондентов из Витебской области (четвертый по значимости ответ) указывают на фактор общности проживания на соседних территориях как основу для сходства русских и белорусов. Для опрошенных молодых людей из Могилева объединяющей также является религия - это четвертый по значимости фактор: 42\% опрошенных (рис. 12.1).

Анализ эмпирических данных, касающихся ответа на противоположный вопрос (об отличии русских от белорусов), позволил выявить ряд закономерностей, а также признаков формирования новых тенденций.

Так, исходя из самых популярных ответов в трех областях, рейтинг критериев отличности двух народов выглядит следующим образом:

1) разная психология (менталитет) - 53\% (респонденты из Витебской области); 
2) разная культура, традиции - 41\% (респонденты Могилевской и Смоленской областей);

3) язык - 37\% (респонденты из Смоленской области).

При этом максимальные цифры первого и третьего критериев имеют место только в одной из областей.

Так, несмотря на 53\%, которые имеют место в Витебской области, молодежь из Могилевской области указывала на фактор ментальных различий двух наций фактически в два раза реже (27\%), Смоленской области - в три раза (18\%). В связи с этим можно предположить, что мнение о различиях в данной сфере является в настоящее время не вполне типичным для всего приграничья.

В лидерах ответов также находится язык. При этом обращает на себя внимание тот факт, что на этот фактор отличия указывает большинство респондентов из Смоленской области. Белорусская часть молодежной аудитории, которая выбрала этот вариант ответа, составляет чуть более $12 \%$. Это может быть связано с тем, что русским сложнее понимать белорусский язык, а частота его употребления (в частности, в белорусском сегменте сети Интернет) увеличивается. В то же время белорусы в быту все так же продолжают в большей степени использовать русский язык.

Наибольший интерес, на наш взгляд, имеют критерии отличия, на которые указали респонденты из всех трех областей (рис. 2).

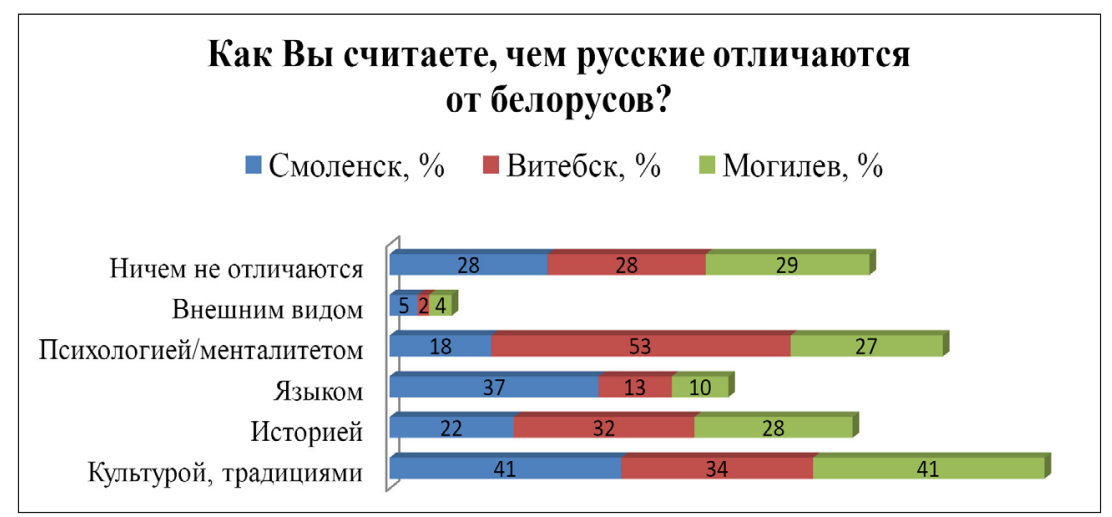

Рис. 2. Отличия русских и белорусов 
Таким образом, в российско-белорусском приграничье основными факторами различия двух народов, по мнению молодых людей до 25 лет, выступают культура, традиции, а также история и менталитет. Также по 28-29\% респондентов в каждом из регионов считают, что русские и белорусы ничем не отличаются.

В то же время обращает на себя внимание тот факт, что ответы на вопросы концентрируются вокруг одних и тех же критериев. Это, во-первых, культура, традиции, во-вторых, общая история. При этом цифры за и против, в целом, сопоставимы (аналогичны). Данный факт может быть свидетельством поляризации общественного мнения. Другими словами, порядка 50\% молодежи полагает, что русских и белорусов объединяет культура, остальные, порядка $40 \%$, считают, что культура и традиции отличают две нации. Аналогичные цифры наблюдаются по вопросу общности истории.

Обозначенная дихотомия также проявляется при ответах на вопрос о том, являются ли русские и белорусы ветвями одного народа или близко родственными народами. Здесь молодое поколение русских и белорусов, в целом, отнесли себя к единой этнической группе. В то же время четко прослеживаются «неожиданные оценки» и разнонаправленные тенденции. Так, респонденты из российской и белорусской частей приграничья все чаще, по сравнению с более старшим поколением, указывают на неодинаковость и наличие специфики у жителей сопредельного государства.

Для понимания того, каковы «перспективы» категории национальной идентичности в структуре ментальности молодого человека, важным является изучение специфики восприятия, уровня доверия друг другу среди русских и белорусов как на бытовом, так и на межгосударственном уровне. Другими словами, необходимо зафиксировать, какова эмоциональная окрашенность взаимоотношений и захочется ли в перспективе молодому человеку и его детям относить себя к этой этнической группе, является ли она для него комфортной, испытывает ли он уважение к чертам национального характера, государственному устройству и т.д. В этой связи респондентам было предложено перечислить 5 вещей, которые сразу приходят в 
голову, когда они думают о России (для белорусских респондентов) и о Беларуси (для российских респондентов).

Так, основными ассоциациями в обоих случаях являются главы государств, города, типичные мифологемы (стереотипы), наиболее яркие бытовые характеристики (рис. 3).

Перечислите пять вещей, которые Вам сразу приходят в голову, когда Вы думаете о Беларуси/России

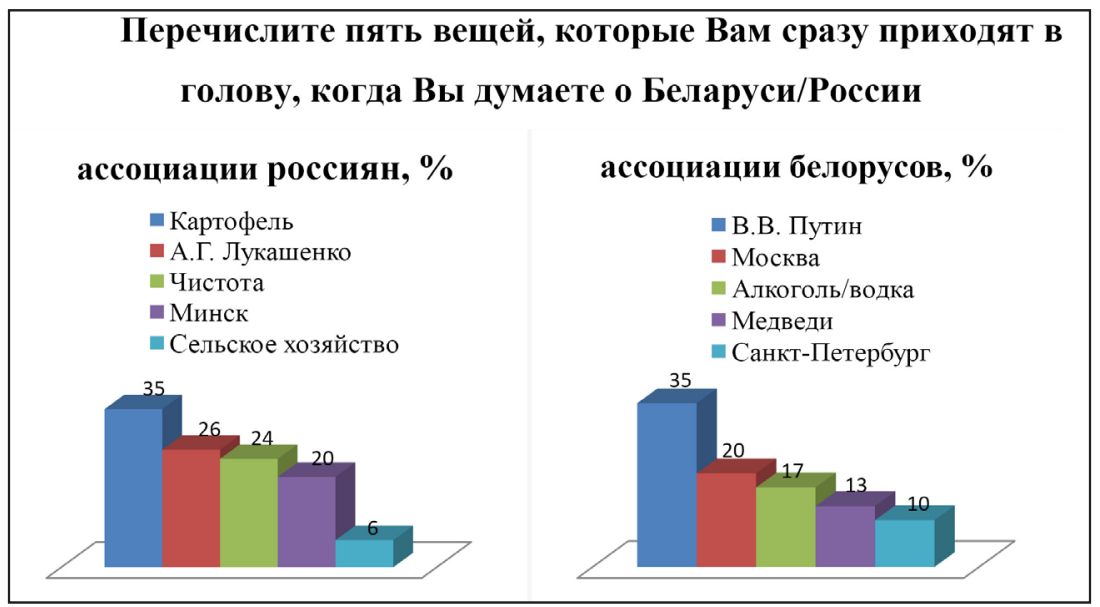

Рис. 3. Ассоциации представителей двух стран по отношению друг к другу

На лично-бытовом уровне проявляется высокая степень лояльности среди молодежи приграничья. Речь, в частности, идет о высоких показателях готовности породниться, создать семью, вместе трудиться, рядом проживать (рис. 4.1, 4.2).

Готовность взаимодействовать на лично-бытовом уровне экстраполируется также на вопросы межгосударственного сотрудничества. Так, чуть более $45 \%$ белорусских респондентов считают, что у Минска на данный момент наиболее близкие, дружественные отношения с Россией. Смоляне на первое место поставили Китай (47\% опрошенных), Беларусь - третья в рейтинге после Казахстана с 9\%. Это может быть связано с тем, что россияне априори не отделяют Беларусь от России. В то же время для дальнейшего развития 
двум странам не хватает, главным образом, доверия (так ответили $25 \%$ витеблян, $21 \%$ могилевчан, $16 \%$ смолян) и взаимопонимания (25\% могилевчан, $15 \%$ витеблян, 9\% смолян). На это указали респонденты из всех регионов.

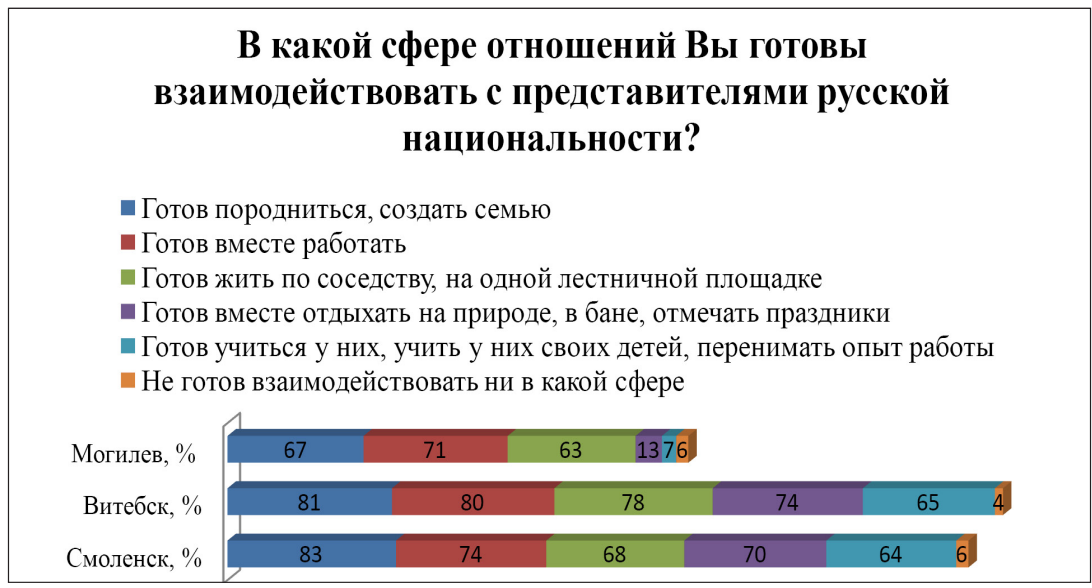

Рис. 4.1. Распределение ответов респондентов по отношению к русским

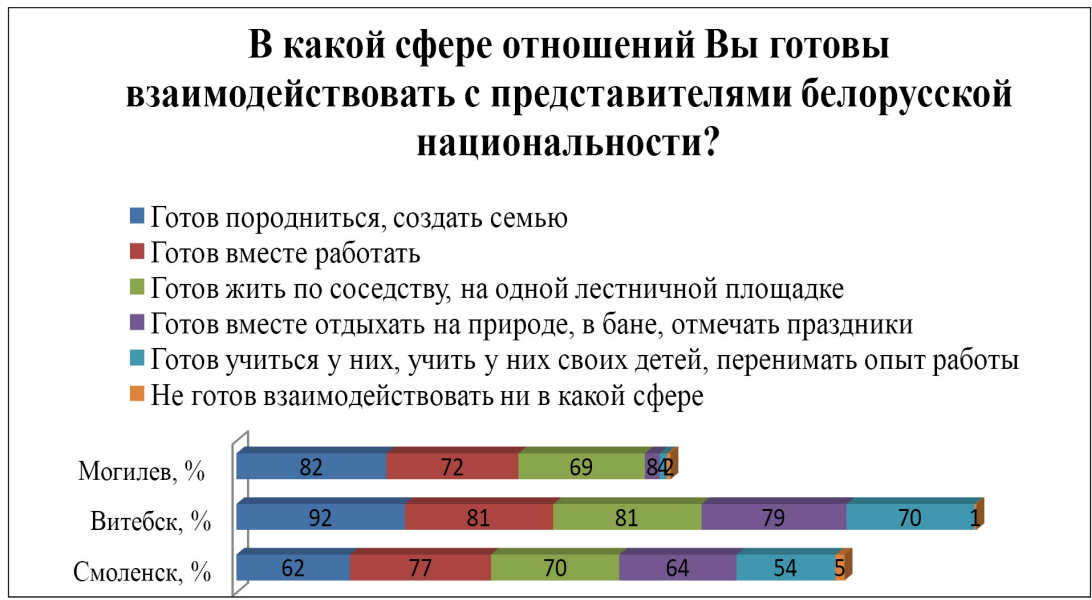

Рис. 4.2. Распределение ответов респондентов по отношению к белорусам

Среди ответов, характерных для одного региона, следующие критерии (таблица 1). 


\section{Рейтинг уникальных ответов по регионам}

Чего не хватает во взаимоотношениях России и Беларуси, что могло бы способствовать их дальнейшему развитию?

\begin{tabular}{cccccr}
\hline $\begin{array}{c}\text { Смоленская } \\
\text { область, \% }\end{array}$ & $\begin{array}{c}\text { Витебская } \\
\text { область, \% }\end{array}$ & \multicolumn{3}{c}{$\begin{array}{c}\text { Могилевская } \\
\text { область, \% }\end{array}$} \\
Всего хватает & $\mathbf{4 0}$ & Доверия & $\mathbf{2 5}$ & Равенства & $\mathbf{2 9}$ \\
Интеграции & $\mathbf{1 9}$ & Всего хватает & $\mathbf{1 7}$ & Взаимопонимания & $\mathbf{2 5}$ \\
Смены власти & $\mathbf{1 6}$ & Грамотных, добросовест- & $\mathbf{1 7}$ & Доверия & $\mathbf{2 1}$ \\
Доверия & $\mathbf{1 6}$ & Взаи политиков & $\mathbf{1 7}$ & Уважения & $\mathbf{1 2}$ \\
Взаимопони- \\
мания & $\mathbf{9}$ & Честности & $\mathbf{1 3}$ & Взаимопомощи & $\mathbf{1 3}$ \\
\hline
\end{tabular}

Таким образом, мы имеем в определенной мере разнонаправленные тенденции в менталитете. С одной стороны, достаточно высокую готовность к сотрудничеству на лично-бытовом уровне, с другой - дефицит доверия в межгосударственных отношениях.

Это в некоторой степени определяет ответы на вопросы о готовности к интеграции между двумя странами (рис. 5).

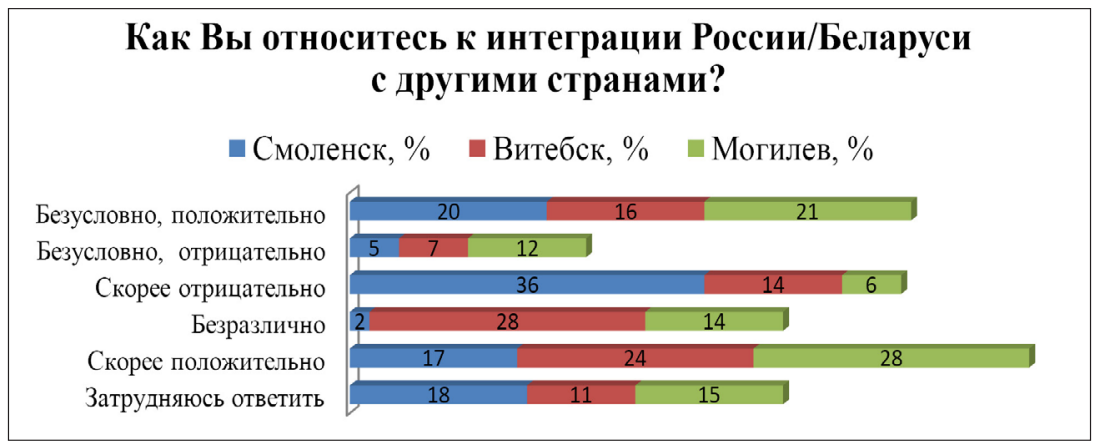

Рис. 5. Отношение респондентов к интеграции

Несмотря на в целом положительное отношение к идее интеграции, молодежь Беларуси скорее против объединения двух стран, тогда как смоленские респонденты - скорее за (рис. 6).

Наиболее желательным вариантом российско-белорусских отношений на сегодняшний день, по мнению респондентов, является 
«независимое существование двух стран с теплыми и дружескими взаимоотношениями» (66\% витеблян, 57\% могилевчан, 56\% смолян) (рис. 7).

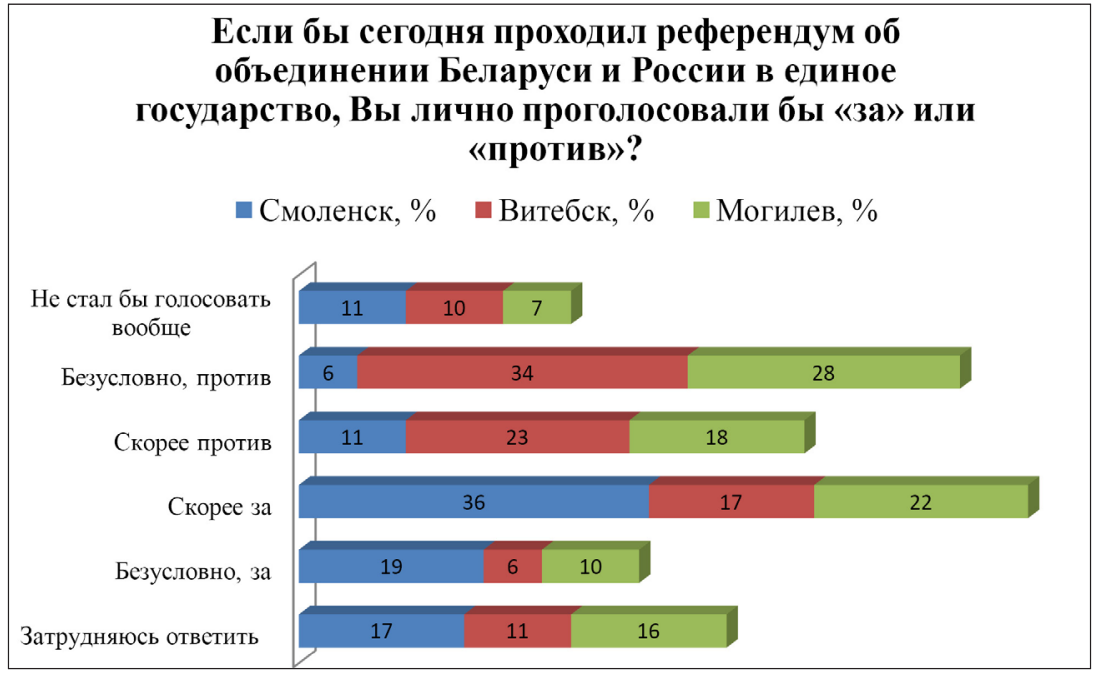

Рис. 6. Отношение к объединению России и Беларуси в единое государство

\section{Какой вариант российско-белорусских взаимоотношений видится Вам на сегодняшний день наиболее желательным?}

- Независимое существование двух стран с холодно-деловыми взаимоотношениями между ними

- Независимое существование двух стран с теплыми и дружескими взаимоотношениями между ними

- Общее (союзное) государство, созданное на равноправной основе

Вхождение Беларуси в состав России

Вхождение России в состав Беларуси

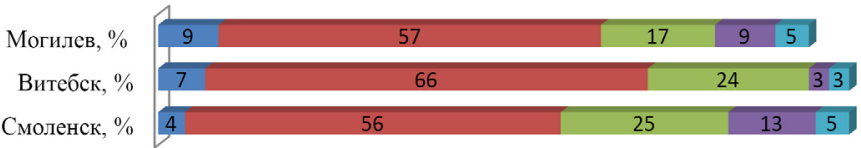

Рис. 7. Отношение к различным формам сотрудничества России и Беларуси

Аналогичное отношение у молодежи приграничья вызывает интеграция трех регионов: Смоленской, Витебской и Могилевской областей - в один. Большая часть против данного вектора развития отношений. При этом также сохраняется выявленный дисбаланс: 
белорусская часть аудитории традиционно настроена более настороженно к процессу интеграции, российская - более лояльно (рис. 8).

\section{Как Вы относитесь к интеграции Смоленской, Витебской, Могилевской областей в один регион?}

- Смоленск, \% — Витебск, \% चогилев, \%

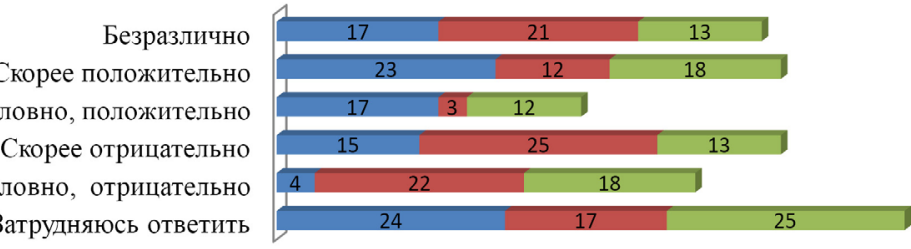

Рис. 8. Отношение респондентов к объединению трех областей

Главной причиной у противников объединения областей является непонимание смысла указанной инициативы и ее последствий для территорий. При этом российские респонденты волнуются, что в случае объединения «появятся нахлебники» (11\%), а белорусские «что увеличится беспорядок» (12,5\%). Это является отражением установок и стереотипов в отношении специфических черт двух народов, сформировавшихся в последнее время.

Выявленные в ходе исследования социально-психологические особенности российско-белорусских приграничных территорий могут быть положены в основу оценки и моделирования поведения субъектов бизнес среды территорий в условиях межгосударственной интеграции, что даст возможность выявлению диспропорций развития данных регионов и неиспользуемых возможностей экономического роста для последующего обоснования вариантов стратегии их социально-экономического развития.

\section{Выводы}

Таким образом, исследование показало, что фактор близости двух народов проявляется как на уровне этнической принадлежности, так и готовности к сотрудничеству и взаимодействию на лично-бытовом 
и межгосударственном уровне. В то же время все ярче проявляются точки разлома: снижение доверия, взаимопонимания, отрицательные мифологемы в отношении двух народов (белорусы - нахлебники, русские - ватники), вызванные в том числе периодическими внешнеэкономическими разногласиями и сопровождающими их информационными кампаниями. В ходе определения ментальных скреп российской и белорусской молодежи проявляются следующие критерии сходства: общее славянское происхождение, история, совместные испытания и победы, культура и язык. Почти треть респондентов в каждом исследуемом регионе однозначно считают, что русские и белорусы ничем не отличаются. В целом молодое поколение двух братских народов относит себя к единой этнической группе. По ряду ответов прослеживается, что русские априори не отделяют Беларусь от России. В качестве отличительных аспектов в Витебской области названа разница в психологии, в Могилевской области - культура и традиции, в Смоленской области - язык. На бытовом уровне проявляется высокая степень лояльности среди молодежи приграничья. Девушки и юноши готовы с соседями породниться, создать семью, вместе трудиться, проживать рядом.

Одной из главных задач исследования стало выявление отношения российско-белорусской молодежи к процессам интеграции России и Республики Беларусь. Несмотря на в целом положительное отношение к россиянам, белорусская молодежь настроена скорее против объединения двух стран, в то время как смоленские респонденты - скорее за. К процессу интеграции в противовес лояльности россиян белорусы относятся отчасти настороженно. Непонимание смысла объединения Смоленской, Витебской, Могилевской областей - основной аргумент противников интеграции. Наиболее оптимальным форматом взаимодействия двух приграничных государств, по мнению респондентов, является «независимое существование двух стран с теплыми и дружескими взаимоотношениями».

Таким образом, мы имеем в определенной мере разнонаправленные тенденции в менталитете. С одной стороны, достаточно высокую готовность к сотрудничеству на лично-бытовом уровне, с другой - 
дефицит доверия в межгосударственных отношениях. Фактором близости является как этническая принадлежность, так и готовность к взаимодействию на лично-бытовом и межгосударственном уровне. В то же время все ярче проявляются точки разлома: снижение доверия, взаимопонимания, а также наличие отрицательных оттенков в русско-белорусской палитре взаимоотношений, связанных с внешнеэкономическими разногласиями и информационными кампаниями.

Для дальнейшего развития, по мнению представителей ДнепроДвинского региона, двум странам не хватает главным образом доверия и взаимопонимания.

Работа выполнена в рамках президентского гранта № 19-1000815 «Днепро-Двинский регион - регион возможностей»

\section{Список литературы}

1. Концепция внешней политики Российской Федерации: утверждена 30 ноября 2016 г. [Электронный ресурс]. https://www.mid.ru/foreign policy/official_documents/-/asset_publisher/CptICkB6BZ29/content/ $\mathrm{id} / 2542248$ (дата обращения: 01.12.2020).

2. Ахвердян Г.К. Национальное государство и национальная идентичность в свете мировых интеграционных процессов // Известия высших учебных заведений. Поволжский регион. Общественные науки. 2012. №1. С. 34-40.

3. Бредихин А.В. Альтернативные славянские идентичности. Вестник славянских культур. 2018. №48 (2). С. 8-18.

4. Еремина Е.В. Понятие региональной идентичности и специфика ее формирования в современной России // Социально-гуманитарные знания. 2012, №5. С. 276-287.

5. Зотова М.В., Гриценко А.А., Себенцов А.Б. Повседневная жизнь в российском пограничье: мотивы и факторы трансграничных практик // Мир России. Социология. Этнология. 2018. №4. С. 35-38.

6. Кацук О.А., Рябых В.Н. Формирование идентичности региона инструментами регионального управления // Социально-экономические явления и процессы. 2017. №6. С. 25-28. 
7. Кириенко В.В. Белорусская ментальность: истоки, современность, перспективы / В.В. Кириенко. Гомель, ГГТУ им. П. О. Сухого, 2009. 319 с.

8. Коновалов С.А. Методические аспекты оценки региональной идентичности как нематериального фактора развития региональной экономики. Ученые записки Тамбовского отделения РоСМУ, (2020). №19. C. 29-35.

9. Кузавко А.С. Результаты исследования потребительских предпочтений в Днепро-Двинском регионе // Экономический журнал. 2019. №3 (55). С. 32-41.

10. Кузнецов А.В., Кузнецова О.В. Изменение роли приграничных регионов в региональной политике стран ЕС и России // Балтийский регион. 2019. Т. 11, № 4. С. 58-75.

11. Чернобровкина Н.И. Индикаторы экономической идентичности населения региона на микро- и макроуровнях // Социально-гуманитарные знания. 2016. №12 (2). С. 14-17.

12. Alexandrov $\mathrm{M}$. The concept of state identity ininternational relations: a theoretical analysis //Journal of International Development and Cooperation. 2003, vol.10, no.1, pp. 33-46.

13. Fritsch M., Wyrwich M. Regional emergence of start-ups in information technologies: the role of knowledge, skills and opportunities // Foresight and STI Governance. 2019, vol. 13, no 2, pp. 62-71.

14. Fujita M., Krugman P., Venables A.J. The spatial economy: cities, regions and international trade. 1999. Cambridge (Mass.): MIT Press.200 p.

15. Kalb D. Identity politics, globalization and the national state // European Societies. 1999, vol. 1, no 2, pp. 269-287.

16. Measuring the digital transformation: a roadmap for the future // Paris: OECD Publishing. 2019.87 p.

\section{References}

1. Kontseptsiya vneshney politiki Rossiyskoy Federatsii [Concept of foreign policy of the Russian Federation] 30.11.2016. https://www.mid.ru/ foreign_policy/official_documents/-/asset_publisher/CptICkB6BZ29/ content $/ \mathrm{id} / 2542248$

2. Akhverdyan G.K. Natsional'noe gosudarstvo i natsional'naya identichnost' $\mathrm{v}$ svete mirovykh integratsionnykh protsessov [National state and 
national identity in the light of world integration processes]. Izvestiya vysshikh uchebnykh zavedeniy. Povolzhskiy region. Obshchestvennye nauki [Proceedings of higher educational institutions. Volga region. Social science], 2012. №1, pp. 34-40.

3. Bredikhin A.V. Al'ternativnye slavyanskie identichnosti. [Alternative Slavic identities]. Vestnik slavyanskikh kul'tur [Bulletin of Slavic cultures], 2018. №48 (2), pp. 8-18.

4. Eremina E.V. Ponyatie regional'noy identichnosti i spetsifika ee formirovaniya $\mathrm{v}$ sovremennoy Rossii [Concept of regional identity and the specifics of its formation in modern Russia]. Sotsial'no-gumanitarnye znaniya [Social and humanitarian knowledge]. 2012, №5, pp. 276-287.

5. Zotova M.V., Gritsenko A.A., Sebentsov A.B. Povsednevnaya zhizn’ v rossiyskom pogranich'e: motivy i faktory transgranichnykh praktik [Everyday life in the Russian border area: motives and factors of cross-border practices]. Mir Rossii. Sotsiologiya. Etnologiya [World of Russia. Sociology. Ethnology.]. 2018. №4, pp. 35-38.

6. Katsuk O.A., Ryabykh V.N. Formirovanie identichnosti regiona instrumentami regional'nogo upravleniya [Formation of regional identity by regional management tools]. Sotsial'no-ekonomicheskie yavleniya i protsessy [Socio-economic phenomena and processes]. 2017. №6, pp. 25-28.

7. Kirienko V.V. Belorusskaya mental'nost': istoki, sovremennost', perspektivy [Belarusian mentality: origins, modernity, prospects]. Gomel', GGTU im. P. O. Sukhogo, 2009. 319 p.

8. Konovalov S.A. Metodicheskie aspekty otsenki regional'noy identichnosti kak nematerial'nogo faktora razvitiya regional'noy ekonomiki [Methodological aspects of assessing regional identity as an intangible factor in the development of the regional economy]. Uchenye zapiski Tambovskogo otdeleniya RoSMU, 2020. №19, pp. 29-35.

9. Kuzavko A.S. Rezul'taty issledovaniya potrebitel'skikh predpochteniy v Dnepro-Dvinskom regione [Results of research on consumer preferences in the Dnipro-Dvina region]. Ekonomicheskiy zhurnal [Economic journal.]. 2019. №3 (55), pp. 32-41.

10. Kuznetsov A.V., Kuznetsova O.V. Izmenenie roli prigranichnykh regionov v regional'noy politike stran ES i Rossii [Changing the role of 
border regions in the regional policy of the EU and Russia]. Baltiyskiy region. [Baltic region] 2019. V. 11, № 4, pp. 58-75.

11. Chernobrovkina N.I. Indikatory ekonomicheskoy identichnosti naseleniya regiona na mikro- i makrourovnyakh [Indicators of economic identity of the region's population at micro-and macro-levels]. Sotsial'no-gumanitarnye znaniya [Social and humanitarian knowledge]. 2016. №12 (2), pp. 14-17.

12. Alexandrov $\mathrm{M}$. The concept of state identity ininternational relations: a theoretical analysis. Journal of International Development and Cooperation. 2003, vol.10, no.1, pp. 33-46.

13. Fritsch M., Wyrwich M. Regional emergence of start-ups in information technologies: the role of knowledge, skills and opportunities. Foresight and STI Governance. 2019, vol. 13, no 2, pp. 62-71.

14. Fujita M., Krugman P., Venables A.J. The spatial economy: cities, regions and international trade. 1999. Cambridge (Mass.): MIT Press.200 p.

15. Kalb D. Identity politics, globalization and the national state. European Societies. 1999, vol. 1, no 2, pp. 269-287.

16. Measuring the digital transformation: a roadmap for the future. Paris: OECD Publishing. 2019.87 p.

\section{ДАННЫЕ ОБ АВТОРАХ}

Кузавко Антон Сергеевич, доцент кафедры экономики, кандидат экономических наук

ФГБОУ ВО «Смоленский государственный университет» ул. Пржевальского, 4, г. Смоленск, Смоленская область, 214013, Российская Федерачия akuzavko@gmail.com

Шевченко Ольга Александровна, кандидат психологических наук, председатель правления Ассочиация «Агентство анализа интеграционных иниџиатив» ул. Бакунина, 10а, г. Смоленск, Смоленская область, 214000, Российская Федерация olg-a.shev@inbox.ru 


\section{DATA ABOUT THE AUTHORS}

Kuzavko Anton Sergeevich, associate professor economics, Candidate of Economic Sciences

Smolensk State University

4, Przhevalsky St., Smolensk, Smolensk region, 214013, Russian Federation

akuzavko@gmail.com

SPIN-code: 4551-0095

ORCID: 0000-0001-9758-3940

ResearcherID: C-4822-2017

Shevchenko Olga Aleksandrovna, Candidate of Psychology Sciences, Chairman of the Board Agency for Analysis of Integration Initiatives 10a, Bakunin St., Smolensk, Smolensk region, 214000, Russian Federation olg-a.shev@inbox.ru 